\title{
A CHALLENGE OF TRUST: CAN DISTRUST KILL THE EURO?
}

\author{
Nataliia KOSTIUCHENKO', \\ Odessa I.I. Mechnikov National University, Ukraine
}

\begin{abstract}
The purpose of the paper is to determine the dynamics of trust in the ECB in the most recent period, to compare the findings with a previous study of Farvaque et al. (2010) and to explore the question of importance of citizen's trust in public institution for the economic performance of the country. This paper is dedicated to the study of the determinants of trust in the European Central Bank. The study attempts to give an answer to a question posed in introduction: can distrust kill the euro? After the world economic crisis the trust in the ECB began to deteriorate. Citizen's trust in public institutions plays an important role for the economic performance of the country. Methology. We rely on the micro data from the European Commission's Eurobarometer survey. This paper contributes empirically to the existing literature dedicated to the issue of trust in public institutions. The responses in $15 \mathrm{EU}$-member countries were taken into account. The present work uses the model of Farvaque et al. (2010) extending the time frame considered previously, giving a broader picture on this issue using the most recent data. Results. In accordance with our findings, the population that support the ECB is approximately equal to the population that does not trust in the community bank, with a mean value of 0,51 . Even if there are still more supporters of the $E C B$, this data should provide an alarm for the European institutional framework, in consideration that in 1999 (in accordance with Farvaque et al. (2010)) the mean value was 0,67. Practical implications. According to our findings, still people with higher level of education, people with a higher social status, people with center or right-wing political orientation, people with optimistic expectations on the economic situation have more trust in the ECB. However, we have found that women have become more supportive about the ECB than men in contrast with the findings of Farvaque et al. (2010). Value/originality. A matter of trust in public institutions represents a great interest for economic research. In the background of the global financial crisis, the trust in central banks has become extremely popular nowadays. Particularly, trust in the European Central Bank in the aftermath of the world economic crisis, concentrating on the period of 2012-2014, is examined.
\end{abstract}

Key words: Trust, Eurobarometer survey, European Central Bank, public opinion.

JEL Classification: E58, Z13, C23

\section{Introduction}

The global financial crisis has become a challenge to the whole world. The European Union is not an exception. In the background of the global financial crisis, the reputation of the European Central Bank (ECB) has become more doubtful. It was criticized not only by citizens, but also by many politicians. Politicians often try to put pressure on the ECB. A question whether distrust may kill the euro arises. It is crucially important that ECB gets more support and trust from the population. It is important to have a transparent communication strategy in order to provide a support for a central bank's policy by the citizens.

Europe has gone through a unique historical process of both economic and political integration in the aftermath of World War II. In the spring of 2010 the worst situation in the sovereign debt crisis was recorded. On January 1, 2011 Estonia introduced the euro on its territory. The Central Bank of Estonia paid in a part of its capital to the ECB capital in a set amount. On January 13, 2011 it was decided to keep the discount rate on the same level (1,00\%). In 2011 the ECB raised the discount rate on April, 13. It comprised $1,25 \%$. From February until April 2012, a sovereign debt restructuring took place in Greece. It was the largest sovereign bond exchange in history (Zettelmeyer et al., 2013). On July, 11 the ECB decreased the discount rate to $0,75 \%$. On July 1, 2013 the Republic of Croatia was accepted to the EU. So, now there are 28 member states in the EU. In November, 2013 the discount rate was on the level of $0,25 \%$. The monetary policy at this period was aimed at support of economic activity and creation of working places (Bespalova, 2012). On January 1, 2014, Latvia became the member of the Eurozone and adopted the euro. The ECB under the supervision of Mario Draghi continues the cheap money policy. On September 4, 2014 the ECB decreased its discount rate by $0,1 \%$ to the level of $0,05 \%$, which has never been so low before. Such radical decision of the ECB made the euro weaker to U.S.

\footnotetext{
Corresponding author

${ }^{1}$ Department of World Economy and International Economic Relations, Odessa I.I. Mechnikov National University.

E-mail: nataliakostiuchenko@gmail.com
} 
dollar. Such situation is profitable for the exporters from the countries of the Eurozone, as their production will automatically become cheaper and more competitive for the final consumer. One of the main aims of the "cheap money" policy of the ECB is support of southern EU economies: Spain, Italy, Portugal, Greece and Cyprus.

A matter of trust in public institutions represents a great interest for economic research. In the background of the global financial crisis, the trust in central banks has become extremely popular nowadays.

A high level of trust in public institutions is crucial for an economic performance of a country, because citizens can devote more time to productive activities if they do not need to think about what actions to undertake in order to secure their safety from ineffective functioning of institutions (Ehrmann et al., 2012). That is why the trust of citizens in policy-making institutions is extremely important for a successful functioning of such institution as ECB. A classical reference to the literature that has focused on interpersonal trust as the main determinant of economic growth is North (1990). However, Putman (1993) investigated what impact social cohesion and trust had on the quality of public policies. Furthermore, Knack and Keefer (1997) have found that interpersonal trust and confidence in government have a positive relation (Erhmann et al., 2012).

In contrast, lack of trust makes the central banks affected by political pressure (Ehrmann and Fratzscher, 2011). Walstad and Rebeck (2002) claim that public viewpoints depend on economic knowledge, which in turn is affected by such factors as education, income, age, gender, race and political party affiliation. Maya and Rodrik (2005) studies attitude to protectionism and find that sociodemographic background, values, identities, attachments explain difference in attitude to trade (Hayat et al. 2012). Hainmueller and Hiscox (2006) find that individuals with college-level education have positive attitude to trade openness rather than those without. A number of studies has been made on whether or not there has been a decline of public confidence in modern institutions among various societies (Newton, Norris, 1999).

Today three schools of thought explaining the erosion of citizen confidence in public institution can be outlined. The first one focuses on the social-psychological features of individuals. The second one looks at the cultural environment of individuals, groups or communities. And the third one concentrates on governmental performance. There are many writers who see trust as a fundamental feature for building stable democracy (Almond and Verba, 1963). Those governmental institutions that perform well generate more confidence of citizens and vice versa. Governmental performance has an influence on individuals no matter of their personality or social type. Inflation, economic growth, government corruption or foreign policy affects citizens to a greater extent than the government performance. For this reason political trust is more or less randomly distributed among people with different individual characteristics (education, income, religion, age, or gender) (Newton, 1999).

Nowadays it is interesting to investigate the effect of the financial crisis on public opinion. Hayo (2005) investigates the trust in public institutions during the Asian financial crisis of 1998-99. He was using the data from South Korea. Another example is the study of Coffey and Hellwig (2011). They study the public opinion of British citizens during the financial crisis. They have found that such factors as education and political orientation play an important role when defining who is responsible for the financial crisis. In accordance with the results of Stevenson and Wolfers (2011), there is a fall in trust in public institutions during the period of Great Recession. Nevertheless, the question of how to measure the level of population's trust remains open. Definitely, it is not an easy task to carry out. There have been attempts of a number of scientists. For instance, Maier and Bezoen (2004). They mainly argue that such organizations as the International Monetary Fund (IMF) and politicians impose pressure on the ECB. Another example is the study of Ehrmann and Fratzscher (2007). They examined the pattern of communication strategies of several central banks, but their evidence is limited to the reactions of financial markets.

In terms of this, the Eurobarometer survey data represents an important source for economic research. Eurobarometer survey represents a large cross-national individual-level survey carried out on behalf of the European Commission since 1973. Each survey conveys around 1,000 face-to-face interviews per member state, up to total 27,000 individuals in EU. An important fact to be considered is that the survey is not a panel. Every time there is a different subject. The question may be repeated in the next year or not.

Hayo (1999) investigates public attitudes to European Monetary Union (EMU), using data from the Eurobarometer 39. He concludes that high awareness of EMU influences public opinion on monetary integration in a positive way. Hayo (1999) and Gärtner (1997) were using such datasets in order to examine macroeconomic and monetary issues. Gabel (1998) using the surveys conducted in the period of 1978-1992 concludes that gender, age and occupation are the relevant variables to consider when explaining support for the European integration process. Kaltenthaler and Anderson (2001) use the data from Eurobaromenter waves 41-47 and analyze the support for a European monetary policy during 1994-1997. They conclude that individuals with dominating national identities show less support for a single currency. Kaltenthaler et al. (2010) investigate the distrust of public attitude to ECB. They have found that when the bank autonomy is too high, the level of distrust rises. Furthermore, women appeared to show less trust to ECB. But those who are older and more educated showed more trust. A study carried out by Ehrmann et al. (2012) represents a great interest. They tried to explain the trust in ECB both in normal times and in crisis times. They come 
up with a conclusion that a higher degree of knowledge about the ECB generates more trust in normal times and even more of it during the financial crisis.

This paper contributes empirically to the existing literature dedicated to the issue of trust in public institutions. The aim of the present study was to determine the dynamics of trust in the ECB in the most recent period and to compare the findings with a previous study of Farvaque et al. (2010). The responses in 15 EU-member countries were taken into account. The main paper we rely on in our study is the one of Farvaque et al. (2012): "Who Supports the ECB? Evidence from Eurobarometer Survey Data”. In this paper the socio-demographic determinants of particularized trust, particularly in an influential institution - the ECB are studied. They rely on microlevel data and cover the period from 1999 until 2011. They focus on the Old EU 15 and New EU 12 countries. The following variables enter the logistic regression: age, education, income, employment, political ideology. They also use macroeconomic variables, such as inflation, real GDP growth, the unemployment rate and inflation. According to their findings, such groups of people support the ECB: people with higher level of education, people with higher level of income, people with center or right-wing political orientation, people with optimistic expectations on the economic situation. In addition, men are more supportive about the ECB than women are, as they are more business involved. The unemployed people show the least level of support in the ECB as well as those with the least level of income and education. In this study, we also consider the socio-demographic determinants of trust in the ECB. We consider the period that has not been examined by Farvaque et al. (2012), namely 2012-2014. We rely on the data from the Eurobarometer surveys 77.3 (May 2012) through 82.3 (Nov. 2014). This period is particularly interesting, because there have been certain changes in the ECB policy and in the composition of member-states in the EU and the Eurozone in the period between the analysis of Farvaque et al. (2012) and ours. We also omit the income factor, that they were using. Instead we include the social class factor in the model. In accordance with our findings, firstly, the population that supports the ECB is approximately equal to the population that does not trust in the community bank, with a mean value of 0,51 . Even if there are still more supporters of the ECB, this data should provide an alarm for the European institutional framework, in consideration with that in 1999 (in accordance with Farvaque et al. (2010)) the mean value was 0,67 . This meaningful drop is strongly affected by the PIIGS Economics crisis in 2012 and the magnitude of this scepticism forced Mario Draghi. Secondly, our results provide that women are more supportive of the ECB in the period considered. It can be explained by the rise of women's involvement in business activity in the recent years and the rise of scepticism about the ECB among men.

This paper is organized in the following way. An introduction provides information on the background of the problem and highlights the existing problems in the field. Section 2 dwells on the literature and previous studies known in the area. Section 3 reports on the data from the Eurobarometer survey, providing us with more details. It is dedicated to a statistical summary and graphs' description. Section 4 talks about econometric estimation of determinants of trust in the ECB. It describes the model employed and the acquired results. Section 5 provides the conclusions on the investigated issue giving a brief summary of our findings.

\section{Data and Statistical Summary}

We consider the period that has not been examined by Farvaque et al. (2012), namely 2012 - 2014. We rely on the data from the Eurobarometer surveys 77.3 (May 2012) through 82.3 (Nov. 2014). Those waves of the survey that include the question on trust in the ECB are selected. Table 1 provides more details.

Table 1

Eurobarometer Data Coverage by Survey Wave

\begin{tabular}{|c|c|c|c|c|c|}
\hline $\begin{array}{c}\text { No in } \\
\text { Our } \\
\text { Sample }\end{array}$ & $\begin{array}{c}\text { Original } \\
\text { No }\end{array}$ & $\begin{array}{c}\text { Original } \\
\text { 4-digit } \\
\text { code }\end{array}$ & Period & Year & $\begin{array}{c}\text { Question } \\
\text { number }\end{array}$ \\
\hline 1 & 77.3 & 5612 & May & 2012 & QA17_4 \\
\hline 2 & 78.1 & 5685 & Nov & 2012 & QA15_4 \\
\hline 3 & 79.3 & 5689 & May & 2013 & QA18_4 \\
\hline 4 & 80.1 & 5876 & Nov & 2013 & QA15_3 \\
\hline 5 & 81.2 & 5913 & March & 2014 & QA10_3 \\
\hline 6 & 81.4 & 5928 & May Jun & 2014 & QA15_3 \\
\hline 7 & 82.3 & 5932 & Nov & 2014 & QA17_3 \\
\hline
\end{tabular}

The waves employed cover 15 countries Namely, old 15 EU member countries (Belgium, Denmark, Germany, Greece, Spain, France, Ireland, Italy, Luxembourg, Netherlands, Portugal, United Kingdom, Austria, Sweden, and Finland). Table 2 provides more details.

Table 2

Eurobarometer Data Coverage by Country

\begin{tabular}{|c|c|}
\hline & EU15: 2012-2014 \\
\hline Code & Name \\
\hline FR & France \\
\hline $\mathrm{BE}$ & Belgium \\
\hline NL & Netherlands \\
\hline $\mathrm{DE}$ & Germany (East+West) \\
\hline IT & Italy \\
\hline LU & Luxembourg \\
\hline $\mathrm{DK}$ & Denmark \\
\hline IE & Ireland \\
\hline GB & Great Britain \\
\hline GR & Greece \\
\hline ES & Spain \\
\hline $\mathrm{PT}$ & Portugal \\
\hline FI & Finland \\
\hline SE & Sweden \\
\hline $\mathrm{AT}$ & Austria \\
\hline
\end{tabular}


A question of a direct interest is the question of trust in ECB (Question No. 17_4 in Eurobarometer 77.3 - May 2012), particularly:

"Q.17 And, for each of them, please tell me if you tend to trust it or tend not to trust it?

\section{Q.17 4 The European Central Bank"}

There are the following responses: 1 for "Tend to trust", 2 for "Tend not to trust", and 3 for "Don't know". We exclude the response that does not express any opinion 3 . There is actually a significant issue in the Eurobarometer survey design, because the question on trust in ECB is connected with questions on trust in other institutions, such as The European Parliament, The European Commission, The Council of Ministers of the European Union etc. Due to unawareness of some respondents about separate roles of every institution, they might give a collective answer to this question. Due to this fact the number of observations falls. That is why it can be said that the survey design is a serious matter (Ehrmann et al., 2012) It is important to consider the variable of the individual level of knowledge about ECB. In the Eurobarometer survey, the following question is asked: "Have you heard about the ECB?" and the possible answers are "Yes" and "No". About $85 \%$ of respondents choose "Yes". Therefore, it is important that those people who have heard about ECB are asked a question about trust to it. (Ehrmann et al., 2012). The sample period for analysis is 2012 2014 - particular years that have not been considered in the paper of Farvaque et al. (2010). From Table 3 we can see that trust in the ECB has considerably declined in the year 2014, especially for such countries, as Italy, Ireland, Greece, Spain and Portugal. Throughout the history, the monetary thought has encompassed various modifications. Different viewpoints have been expressed depending on the period of development of economic thought and on the general political situation in the world, either war or an economic crisis. Monetary economics has both a microeconomics and a macroeconomics part. Among variables influenced by the shifts in the supply and demand for money are the following variables: national output, employment, the rate of unemployment, exports and imports, exchange rates and the balance of payments. In 2013 the unemployment level in Greece comprised 28\%, in Spain it increased significantly in 2013 and was at the level of $27 \%$. In Ireland it was 12\%, in Italy - 13\%, in Portugal 15\% and in Cyprus 18\%. In Spain there is a slight reduction in unemployment, but it can be explained by the rise in emigration of the unemployed. The level of youth unemployment is striking. In Greece the youth under age of 25 was 59\% in the end of 2013. In Spain the number is even more striking - 54\%. In Italy this number is less - 42\%. In Portugal it comprises 36\%. However, in Germany only 7,4\% of unemployment among youth is recorded. This is due to its vocational training scheme. High rates of unemployment result in mass protests and social unrest. In Spain in 2011 there was a number of demonstrations in around fifty cities. In 2012, about one million people participated in demonstrations in Portugal. In Greece demonstrations have become a common issue. Over 100,000 people went on demonstrations in Italy. Due to losses of euro and the deterioration in the economic situations in countries, concern of people grows. We can see from the table that the numbers are striking also in Germany and France for the year 2014. For example, in Germany the number of respondents, who showed distrust in the ECB in the year 2012 comprised 824 respondents. In the year 2013 it has increased up to 1610 respondents. Finally in 2014 even more people were disbelieved, particularly 2549 respondents. This can be explained by the following. On September 4, 2014 the ECB decreased its discount rate by $0,1 \%$ to the level of $0,05 \%$, which has never been so low before. Such radical decision of the ECB made the euro weaker to U.S. dollar. Such situation is profitable for the exporters from the countries of the Eurozone, as their

Table 3

Trust in the European Central Bank (ECB) in 15 EU countries, 2012-2014

\begin{tabular}{|l|c|c|c|c|c|c|c|}
\hline \multirow{2}{*}{ Country } & \multirow{2}{*}{ Code } & \multicolumn{2}{c|}{2012} & \multicolumn{2}{c|}{2013} & \multicolumn{2}{c|}{2014} \\
\cline { 3 - 8 } & & For & Against & For & Against & For & Against \\
\hline France & FR & 1,211 & 607 & 600 & 1,058 & 855 & $\mathbf{1 , 6 3 2}$ \\
\hline Belgium & BE & 1,461 & 565 & 1,013 & 923 & 1,326 & 1,384 \\
\hline Netherlands & NL & 1,593 & 333 & 1,064 & 801 & 1,675 & 992 \\
\hline Germany (East+West) & DE & 2,080 & 824 & 1,151 & 1,610 & 1,658 & 2,549 \\
\hline Italy & IT & 1,059 & 785 & 593 & 1,093 & 740 & $\mathbf{1 , 6 7 7}$ \\
\hline Luxembourg & LU & 728 & 198 & 579 & 284 & 763 & 502 \\
\hline Denmark & DK & 1,597 & 281 & 1,277 & 466 & 1,787 & 737 \\
\hline Ireland & IE & 1,219 & 592 & 672 & 1,069 & 853 & $\mathbf{1 , 6 4 7}$ \\
\hline Great Britain & GB & 902 & 902 & 411 & 1,109 & 614 & 1,498 \\
\hline Greece & GR & 1,096 & 872 & 340 & 1,599 & 528 & $\mathbf{2 , 3 8 7}$ \\
\hline Spain & ES & 1,114 & 766 & 347 & 1,479 & 512 & $\mathbf{2 , 2 3 5}$ \\
\hline Portugal & PT & 1,272 & 609 & 580 & 1,263 & 932 & $\mathbf{1 , 8 7 2}$ \\
\hline Finland & FI & 1,522 & 393 & 1,132 & 685 & 1,889 & 808 \\
\hline Sweden & SE & 1,593 & 358 & 1,132 & 706 & 1,629 & 1,000 \\
\hline Austria & AT & 1,387 & 501 & 936 & 894 & 1,371 & 1,385 \\
\hline Total & & 19,841 & 8,586 & 11,827 & 15,039 & 17,132 & 22,305 \\
\hline
\end{tabular}


production will automatically become cheaper and more competitive for the final consumer. One of the main aims of the "cheap money" policy of the ECB is support of southern EU economies: Spain, Italy, Portugal, Greece and Cyprus. In this case, the northern countries, particularly their citizens are losing. In Germany, for example, the old-age welfare is based on withholdings during a working age and also on how much the pension funds will be able to earn, that invest these withholdings in stocks, real estate and other actives. However, if the discount rate of the ECB is low, then the percent generated by the actives remains low, and as a result the possibility to get a reasonable percent raise to pension is equal to zero. In other words, German pensioners finance the debts of Greece and Cyprus. Apart from this, pensioners from Finland, Luxembourg and the Netherlands are in the same situation. Moreover, the burden is hanging not only on the pensioners, but also on all the citizens who have bank deposits. Even without knowing it they transfer a part of percent to the virtual fund bailing out the Southern Europe. The country that was mostly disbelieved about the ECB already in the year 2012 was Great Britain - 902 respondents gave an answer "Tend not to trust". However, that number has risen not so much in the following years: 1109 and 1498 in the years 2013 and 2014 respectively. An interesting observation about Great Britain is that in the year 2012 half of respondents gave a positive answer and another half a negative one. Nevertheless, more people showed a tendency not to trust in the ECB in the following years.

On the other hand, in Greece more people still tended to trust in the ECB in 2012, however this trend has changed in the years 2013 and 2014. The same picture is observed in such countries as Ireland, Spain, Portugal, Italy and France. In the year 2012 those countries showed more trust in the ECB in comparison with the following years. The counties that showed more trust in ECB during all the 3 years are the Netherlands, Denmark, Finland, Sweden and Austria.

Average support for the ECB by country is illustrated in Figure 1, taken as a long-run average across the Eurobarometer survey waves. Average level of trust is higher in Denmark, Sweden and Netherlands. Almost $80 \%$ of respondents tend to trust in the ECB. By contrast, in Great Britain only $50 \%$ tend to trust in the ECB. In Greece and Spain the minimum level of trust in the ECB is the least - nearly $20 \%$.

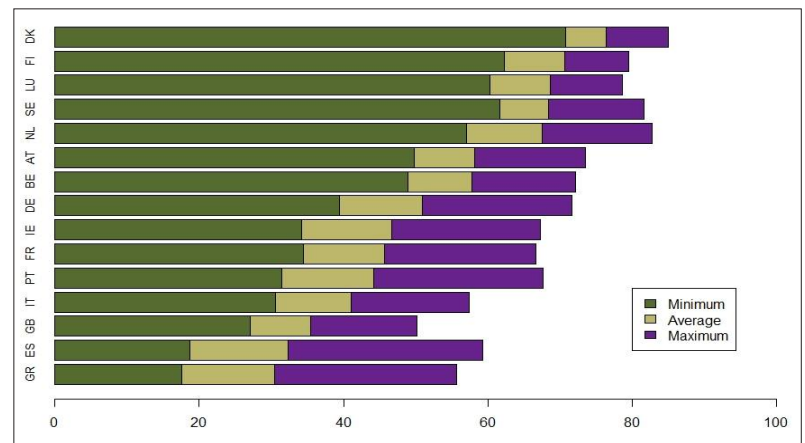

Source: Author's calculations based on Eurobarometer survey data Fig. 1. Average Support For The ECB By Country, \% - EU15, 2012-2014
The annual evolution of the level of trust in the ECB by country is demonstrated in Figure 2. The lowest level of trust is observed in almost all the countries in 2013. This can be attributed to the ECB policy in that period. In November, 2013 the discount rate was on the level of $0,25 \%$. Then the level of trust gradually increases by the year 2014. The "cheap money policy" proves to bring positive results. Figure 3 reveals the change in the distribution of trust in the ECB in the Old EU15 countries in the period 2012-2014 in terms of boxplot diagram. From 2012 the trust in the ECB has significantly deteriorated (the mean goes from $70 \%$ to $40 \%)$.

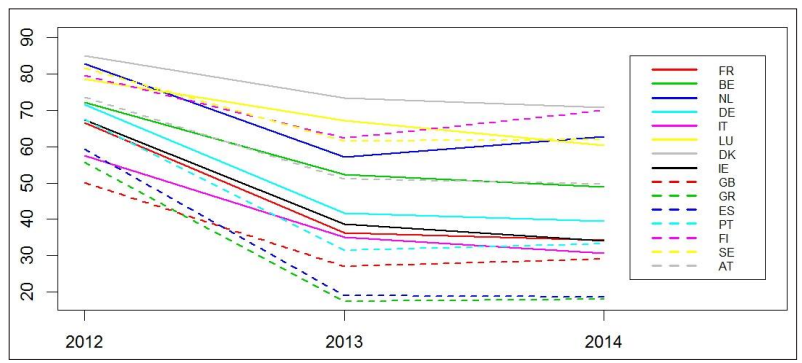

Source: Author's calculations based on Eurobarometer survey data Fig. 2. Trust In The ECB By Country, \% - EU15, 2012-2014

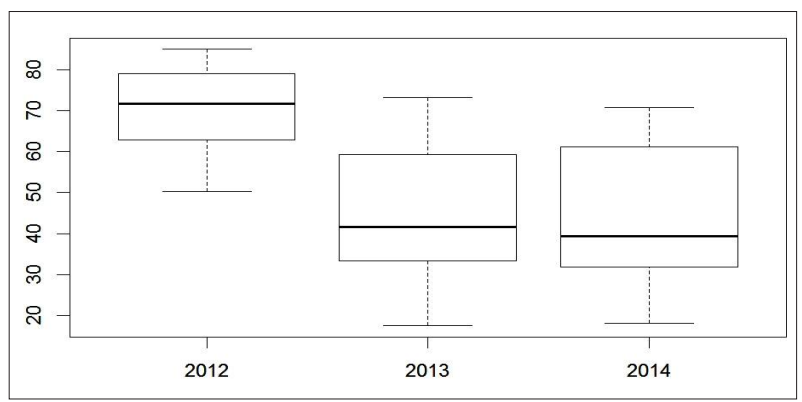

Source: Author's calculations based on Eurobarometer survey data Fig. 3. Distribution of Trust in the ECB, \% - EU15, 2012-2014 - Boxplots

Table 4 provides summarystatistics in the Eurobarometer survey across its main socio-demographic categories and groupings. The respective means give an impression about who supports the ECB to a less or a bigger extent. Firstly, the population that support the ECB is approximately equal to the population that does not trust in the community bank, with a mean value of 0,51 . Even if there are still more supporters of the ECB, this data should provide an alarm for the European institutional framework, in consideration that in 1999 (in accordance with Farvaque et al. (2010)) the mean value was 0,67 . This meaningful drop is strongly affected by the PIIGS Economics crisis in 2012 and the magnitude of this scepticism forced Mario Draghi to claim the famous sentences "is ready to do whatever it takes to preserve the Euro. And believe me, it will be enough" in order to mitigate the speculative financial attack.Referring to the population characteristics, the gender sex is not so much relevant, with the male population that weakly tends to have negative impressions, with a value of 0.48 , 
Table 4

Trust in the ECB by Socio-Demographic Category Summary Statistics. Source: Author's calculations based on Eurobarometer survey data

\begin{tabular}{|c|c|c|c|}
\hline & Mean & $\begin{array}{l}\text { Standard } \\
\text { Deviation }\end{array}$ & Observations \\
\hline Full Sample & 0.51 & 0.5 & 106789 \\
\hline \multicolumn{4}{|l|}{ Gender } \\
\hline Male & 0.4878211 & 0.4998569 & 55742 \\
\hline Female & 0.5432099 & 0.4981347 & 51047 \\
\hline \multicolumn{4}{|l|}{ Age } \\
\hline $15-24$ years & 0.5168488 & 0.4997445 & 10424 \\
\hline 25-39 years & 0.4957416 & 0.4999942 & 22771 \\
\hline $40-54$ years & 0.5126274 & 0.4998506 & 27317 \\
\hline 55 years and older & 0.5259766 & 0.4993309 & 46277 \\
\hline \multicolumn{4}{|l|}{ Education } \\
\hline Up to 15 years & 0.3854239 & 0.4867084 & 21541 \\
\hline $16-19$ years & 0.4736091 & 0.4993105 & 37955 \\
\hline 20 years and older & 0.6199971 & 0.4853943 & 37320 \\
\hline Still studying & 0.5443505 & 0.4980588 & 9973 \\
\hline \multicolumn{4}{|c|}{ Political Placement (data available only 2014) } \\
\hline Left & 0.419105 & 0.4934338 & 13250 \\
\hline Center & 0.4474816 & 0.4972514 & 16817 \\
\hline Right & 0.5389294 & 0.4985125 & 9246 \\
\hline \multicolumn{4}{|c|}{ Economic Expectations } \\
\hline Same & 0.57 & 0.49 & 60501 \\
\hline Better & 0.61 & 0.49 & 18213 \\
\hline Worse & 0.33 & 0.47 & 28075 \\
\hline \multicolumn{4}{|l|}{ Class } \\
\hline $\begin{array}{l}\text { The working class of } \\
\text { society }\end{array}$ & 0.4256431 & 0.4944501 & 35599 \\
\hline $\begin{array}{l}\text { The middle class of } \\
\text { society }\end{array}$ & 0.5402838 & 0.4983807 & 53165 \\
\hline $\begin{array}{l}\text { The upper class of } \\
\text { society }\end{array}$ & 0.5750319 & 0.494349 & 32887 \\
\hline \multicolumn{4}{|l|}{ Occupation } \\
\hline Unemployed & 0.3840563 & 0.4863989 & 9935 \\
\hline Retired & 0.5258903 & 0.499338 & 32359 \\
\hline
\end{tabular}

meanwhile the female population tends to trust in the European Central Bank. On the other hand, it is worth noting that the scepticism among men are bigger than among women. The age of the population is also not relevant in terms of a trust deviation. In particular, it can be noticed that all the mean values tend to the central value of 0.5 , with a small negative deviation for the $25-39$ years part of the population and a small positive deviation for the oldest part of the population. These modest differences are surely correlated to the unemployment crisis that the PIGS country are experiencing in this economic period. Differently to the previous data, the education is strongly spread out in function of the age when the person interviewed had ended to study.

In fact, the part of the population that are ended up to 15 years of education is significantly sceptical about the ECB, with a mean value of 0,38 . The under-educated are usually the part of population that own less income because of the low salary gained doing a job that requires low skills (Miller, 1960; Schulz, 1961; David 1963). Furthermore, in the last economic crisis the poorer part of the population was more affected by the economic recession, with a lower salary and more unemployment, causing an important disbelief in the European Central Bank policy. The poverty condition can be also a caused by the wish of change from the actual framework. It is worth noting that also the second educational population interval, 16-19 years, tends to have a discordant belief about the ECB, with a mean value of 0,49 . On the contrary, the over-educated part of the population, with more than 19 years of education, puts a meaningful trust in the European Bank. This could be explained at first with the same argument of the undereducated. There is in fact a strong positive evidence between levels of education and earning, so this part of population tends also to have a lower impact on the wellness and, apart from that, this part of population has consequently an important desire of stability. We should also highlight the balance between the lower educated and the uppereducated, since the average value between those two is approximately equal to 0.50 , namely the equality between trust and distrust. This has a double relevance: at first, as the medium class is also approximately equal to 0.5 , the education in average does not move the preference of the entire population on the ECB policy; secondly, this gap shows also that the deviation from the central 0,5 value has the same magnitude, 0.11 . For this data, the difference between the 1999 values should be compared: at this period all the population was more optimistic about the ECB. The political preferences show a tendency not to trust in the $\mathrm{ECB}$, as the major part of the left and centre political electors do not support the European bank institution, with a value of 0,45 for centre and mostly with a value of 0,42 for the left. On the contrary, the right has a weak tendency to trust in the ECB. These values shows at first that the preference "goes" from the left, akin to the Keynesian economy and for that reason this part of population wishes a government intervention in order to support the economy, to the right, that on the opposite are akin to the conservative policies, almost always adopted by the ECB.

The economic expectation about the future are strongly correlated with the trust or not trust in the European Central Bank, as the worse expectation mean value is strongly lower than 0,5 , with a value of 0,33 . It is straightforward that who does not put his trust in the ECB has also a pessimistic point of view, and the magnitude of the pessimism is bigger than the optimism of the population that trust in the ECB, with a value of 0,61 . This data, collected in 2014, is not so much affected by the LTRO announcement in July 2014 and mostly is not influenced by the first QE implemented by the European Central Bank, decided on the 22nd of January 2015 in order to stabilize the inflation to the $2 \%$ value. It is also important to highlight the dramatic drop of the value in comparison with the 1999 values, with a loss of 0,17 in mean for the optimistic expectations and a loss of 0,24 for the pessimistic one. The class divisions has roughly 
the same value of the education interval values: in fact, the working class of the society has a meaningful disbelief for the ECB, but this is approximately compensated by the trust of the upper class.

Finally, it is worth emphasizing how much the unemployed do not trust in the ECB. This data can be seen as a result of the economic condition, also keeping in mind that the unemployment issue was not considered as a target for the ECB until the economic crisis of 2012. It is also straightforward that this data is a consequence of richness loss caused by the crisis that caused an increment of the unemployment rate.

\section{Econometric Estimation of Determinants of Trust in the ECB}

The model of Farvaque et al. (2010) is employed: Trust $\left._{i j t}=f\left(\operatorname{Inf}_{i t}, \operatorname{Dem}_{\mathrm{ijt}}, \mathrm{Pol}_{\mathrm{ijt}}\right), \operatorname{EcoExp}_{\mathrm{ijt}} \mathrm{D}_{\mathrm{jt} \mathrm{t}^{\prime}} \mathrm{C}_{\mathrm{j}}, \mathrm{T}_{\mathrm{t}} \mathrm{c}\right)+\epsilon_{\mathrm{ijt}}$ Trust $_{i j t}$ is the opinion of a respondent $i$ in country $j$ at the time/wave $t$ of the Eurobarometer survey. Inf_it is the measure of inflation at $t$ in the $j$-th country. Dem' ${ }_{\mathrm{ijt}}$ is a vector of "demographic variables" such as age, gender, education, employment status. The income variable was omitted in our calculations. Instead, we introduced the variable of the social class in society. Pol' is a vector of "political variables", such as the polital ideology of the $\mathrm{i}$-th respondent in the $j$-th country at $t$, and the trust in the European Commission. EcoExp $\mathrm{E}_{\mathrm{ijt}}$ are the expectations regarding the future economic situation by the respondent. $C_{i}$ represent the country-fixed effects, $T_{t}$ - time/wave fixed effects, $\epsilon_{i j t}$ is the error term of the regression, $\mathrm{c}$ is the constant term. In the paper of Farvaque et al. (2010) the following variables are recognized to determine the trust in ECB, namely: education, age, gender, income, employment, political ideology, trust in European Commission, expectations about economic situation. Apart from this, we include a number of macroeconomic variables at the country level, such as GDP per capita (expressed in constant national currency per person), unemployment rate and inflation (CPI). Data comes from the International Monetary Fund. Table 5 reports about the results.

The model shows at first the insignificance of the inflation on the trust in the ECB, as the regressand is not significantly different from zero. The other characteristics took into account on the questionnaire that are not meaningful are the age (since the interviewed are not older than 54 years) and the political preference for the center. The strongest variable that influences the trust is the occupation, with a strong significant negative impact for the trust as the individual is unemployed, with a value of $-1,29$. Negative impact on the trust has also a situation of being retired, with a value of the regressor of -0,97. A meaningful impact also have the years of education, in particular the more years the individual studies the more the trust to the ECB he has. The social class affinity is also significant for the trust, in particular if the individual belongs to the upper class. The effect of the economic expectation are approximately equal, with a small tendency to the negative impact caused
Table 5

Evolution of Trust in the ECB

after the Financial Crisis - EU15, 2012-2014

\begin{tabular}{|l|c|c|}
\hline \multicolumn{2}{|c|}{ Regressors } & \multicolumn{2}{c|}{$2012-2014$} \\
\hline Inflation $(t)$ & -0.005 &. \\
\hline Gender (BL: Male) & 0.235 & $* * *$ \\
\hline Female & & \\
\hline Age (BL: 15-24 years) & -0.042 & \\
\hline 25-39 years & 0.021 & \\
\hline 40-54 years & 0.392 & $* *$ \\
\hline 55 years and older & & \\
\hline Education (BL: up to 15 years) & 0.326 & $* * *$ \\
\hline 16-19 years & 0.706 & $* * *$ \\
\hline 20 years and older & 0.458 & $* * *$ \\
\hline Still studying & & \\
\hline Political Placement (BL: Left) & 0.162 & $* * *$ \\
\hline Center & 0.346 & $* * *$ \\
\hline Right & & \\
\hline Occupation & -1.249 & $* * *$ \\
\hline Unemployed & -0.979 & $* * *$ \\
\hline Retired & & \\
\hline Class (BL: The lower class of society) & 0.400 & $* * *$ \\
\hline The middle class of society & 0.583 & $* * *$ \\
\hline The upper class of society & & \\
\hline Economic Expectations (BL: Same) & & \\
\hline Worse & & \\
\hline Better & & \\
\hline
\end{tabular}

Significativity codes: ${ }^{* * *} 0.001 ;^{* *} 0.01 ;{ }^{*} 0.05 ; .0 .1 ;^{\prime \prime} 1$

by pessimistic expectation (-0,62) against a positive effect of optimistic expectation. Finally, small but significant positive effect have being affined to the right policy point of view and the gender.

\section{Conclusions}

Comparing the results of Farvaque et al. (2010) it can be said, that considerable difference hasn't been noted. According to our findings, still people with higher level of education, people with a higher social status, people with center or right-wing political orientation, people with optimistic expectations on the economic situation have more trust in the ECB. However, we have found that women have become more supportive about the ECB than men in contrast with the findings of Farvaque et al. (2010). It can be explained by the higher level of women's involvement in business activity in recent years and because women become more educated and politically involved and that is why they are more confident about the ECB. Factors that influence the trust in the ECB the most are: occupation, years of education, the social class. As to our findings, a socio-demographic portrait of a person who has a high level of trust in the ECB looks as follows: it is a well-educated, employed woman in her fifties that belongs to the upper class of society, has center or right political affiliation and has positive expectations about the economic situation in the country. Definitely, a trust in public institution as the ECB has been deteriorated due to the PIIGS Economics crisis in 2012. The north has 
to finance the debts of the south. Trust in the ECB has considerably declined in the year 2014; the numbers in Germany and France for the year 2014 are striking. Most visible decline of trust was recorded in Italy, Ireland, Greece, Spain and Portugal. So does it mean that distrust can kill the euro? We should take into consideration the fact that new countries still keep joining the Eurozone as well as the EU. However, it can be also claimed that the world economic crises has revealed the disadvantages of the European system. During crisis, the main objective of a central bank is to bail out institutions and markets. The Euro system needs to monitor the banking and financial system in its jurisdiction. It also should develop and keep up with the regulatory and supervisory policies and practices. The situation when it will be possible to tell that distrust might kill the euro is only possible in the case if the most crisis-affected countries decide to abandon the euro and leave the Euro system.

\section{References}

Banducci, S.A., Karp, J.A., Loedel, P.H. (2009). Economic interests and public support for the euro. Journal of European Public Policy, Vol. 16, issue 4, p. 564-581.

Dalton, R.J. (1999). Political Support in Advanced Industrial - Oxford University Press, p. 57-77.

De Grauwe, P. (2010). Crisis in the eurozone and how to deal with it - CEPS Policy Brief, 204 p.

Dedman, M.J. (1996). The Origins and the Development of the European Union: 1945-95 - Routledge, p. 70.

Ehrmann, M., \& Fratzscher, M. (2007). Communication by central bank committee members: Different strategies, same effectiveness? - Journal of Money, Credit and Banking, Vol.39, issue 2-3, p. 509-541.

Fligstein, N., Mara-Drita, I. (1996). How to Make a Market: Reflections on the Attempt to Create a Single Market in the European Union - American Journal of Sociology, Vol. 102, issue 1, p. 1-33.

Gabel, M. (1998). Public support for European integration: An empirical test of five theories - The Journal of Politics, Vol. 60, issue 02, p. 333-354.

Gerlach, S., \& Lewis, J. (2014). Zero lower bound, ECB interest rate policy and the financial crisis - Empirical Economics, Vol. 46, issue 3, p. 865-886.

Gros, D., \& Roth, F. (2010). The financial crisis and citizen trust in the European Central Bank - CEPs working document, $334 \mathrm{p}$.

Nelsen, B.F., \& Guth, J.L. (2000). Exploring the gender gap women, men and public attitudes toward European Integration - European Union Politics, Vol.1, issue 3, pp. 267-291.

Hainmueller, J., \& Hiscox, M.J. (2006). Learning to love globalization: Education and individual attitudes toward international trade - International Organization, Vol. 60, issue 02, p. 469-498.

Hall, P.A. (2012). The mythology of European monetary union - Swiss Political Science Review, Vol. 18, issue 4, p. 508-513.

Hayat, M.A., \& Farvaque, E. (2012). Public attitudes towards central bank independence: Lessons from the foundation of the ECB - European Journal of Political Economy, Vol. 28, issue 4, p. 513.

Hayo, B. (1998). Inflation culture, central bank independence and price stability - European Journal of Political Economy, Vol. 14, issue 2, p. 241-263.

Hayo, B. (1999). Estimating a European demand for money - Scottish Journal of Political Economy, Vol. 46, issue 3, p. 221-244.

Houthakker, H.S. (1961). The present state of consumption theory - Econometrica: Journal of the Econometric Society, p. 704-740.

Inglehart, R., \& Norris, P. (2000). The developmental theory of the gender gap: Women's and men's voting behavior in global perspective - International Political Science Review, Vol. 21, issue 4, p. 441-463.

James H., (2012). Making the European Monetary Union - Harvard University Press, p. 324-325.

Kaltenthaler, K.C., \& Anderson, C.J. (2001). Europeans and their money: Explaining public support for the common European currency - European Journal of Political Research, Vol. 40, issue 2, p. 139-170.

Kaltenthaler, K., Anderson, C.J., \& Miller, W.J. (2010). Accountability and independent central banks: Europeans and distrust of the European Central Bank - JCMS: Journal of Common Market Studies, Vol. 48, issue 5, p.1261-1281.

Morselli et al. (2012). Human values and trust in institutions across countries: A multilevel test of Schwartz's hypothesis of structural equivalence - In Survey Research Methods, Vol. 6, issue 1, p. 49-60.

Maier, P., \& Bezoen, S. (2004). Bashing and supporting central banks: the Bundesbank and the European Central Bank - European Journal of Political Economy, Vol. 20, issue 4, p. 923-939.

Rigobon, R., \& Rodrik, D. (2005). Rule of law, democracy, openness, and income - Economics of transition, Vol. 13, issue 3, p. 533-564.

Miller, H.P. (1960). Annual and lifetime income in relation to education: 1939-1959 - The American Economic Review, p. 962-986.

Minkkinen, P., \& Patomäki, H. (Eds.) (1997). The politics of economic and monetary union - Kluwer Academic, p. 7-9. 
Mishler, W., \& Rose, R. (1997). Trust, distrust and skepticism: Popular evaluations of civil and political institutions in post-communist societies - The journal of politics, Vol. 59, issue 2, p. 418-451.

Morgan, J., \& David, M. (1963). Education and income - The Quarterly Journal of Economics, p. 423-437.

Musiąkovska, I. (2014). Enlargements of the European Union - Poznan University of Economics, p. 142-146.

Newton, K. (1997). Social capital and democracy - American behavioral scientist, Vol. 40, issue 5, p. 575-586.

Newton, K., \& Norris, P. (1999). Confidence in Public Institutions: Faith, Culture or Performance - Atlanta, Paper at the annual meeting of the American Political Science Association, p. 2-5.

Nye, J.S., Zelikow, P., \& King, D.C. (1997). Why people don't trust government - Harvard University Press, p. 263-264.

OECD, (1999), EMU. Facts, Challenges and Policies.

Padoa-Schioppa, T. (2004). The Euro and its Central Bank - MIT Press, p. 14.

Frankel, J.A., \& Rose, A.K. (1998). The endogenity of the optimum currency area criteria - The Economic Journal, Vol. 108, issue 449, p. 1009-1025.

Sinn, H.W., (2014). The Euro Trap. On Bursting Bubbles, Budgets, And Beliefs - Oxford University Press, p. 26.

Trichet, J.C. (2010). State of the Union: The Financial Crisis and the ECB's Response between 2007 and $2009-$ JCMS: Journal of Common Market Studies, Vol. 48, issue 1, p. 7-19.

Walstad, W.B., \& Rebeck, K. (2002). Assessing the economic knowledge and economic opinions of adults - The Quarterly Review of Economics and Finance, Vol. 42, issue 5, p. 921-935.

Zettelmeyer, J., Trebesch, C., \& Gulati, M. (2013). The Greek debt restructuring: an autopsy - Economic Policy, Vol. 28, issue 75 , p. 513-563.

\section{Наталья КОСТЮЧЕНКО \\ ИСПЫТАНИЕ ДОВЕРИЕМ: НЕДОВЕРИЕ МОЖЕТ УБИТЬ ЕВРО?}

Аннотация. Целью работы является определение динамики доверия к Европейскому Центральному Банку в современном периоде и сравнить результаты с предыдущим исследованием Farvaque et al. (2010), а также исследовать вопрос важности доверия населения к государственным организациям для экономической ситуации в стране. Данная работа посвящена изучению факторов, определяющих доверие к ЕЦБ. Методика. Мы используем данные из опроса под названием «Евробарометр» Европейской Комиссии. Мы рассматриваем данные в 15-ти странах-членах ЕС. Проведенное исследование даёт ответ на вопрос: может ли недоверие убить евро? Данное исследование использует модель Farvaque et al. (2010), расширяя временные рамки более ранним периодом. Результаты. После мирового финансового кризиса доверие к ЕЦБ значительно уменьшилось. В соответствии с нашими результатами, население, которое поддерживает ЕЦБ приблизительно равно населению, которое не поддерживает общественный банк. Практическое значение. В соответствии с нашими результатами, население с более высоким уровнем образования, с более высоким социальным статусом, с центральной или правой политической ориентацией, с положительными ожиданиями о будущем больше доверяют ЕЦБ. Однако, мы отметили, что женщины стали больше доверять ЕЦБ по сравнению с результатами Farvaque et al. (2010). Значение/оригинальность. Вопрос доверия к государственным организациям представляет большой интерес для экономического исследования. Вследствие мирового финансового кризиса, доверие к европейскому центральному банку стало очень актуальным вопросом. В частности, доверие к Европейскому Центральному Банку после мирового финансового кризиса, в период с 2012 по 2014 гг., который исследован в данной статье. 